\title{
Considerations on a New Form of Ironclad Proposed
}

\section{Captain John Wheatley R.N.}

To cite this article: Captain John Wheatley R.N. (1871) Considerations on a New Form of Ironclad Proposed, Royal United Services Institution. Journal, 15:64, 476-486, DOI: 10.1080/03071847109425422

To link to this article: http://dx.doi.org/10.1080/03071847109425422

$$
\text { 曲 Published online: } 11 \text { Sep } 2009 .
$$

Submit your article to this journal $\sqsubset \pi$

Џ Article views: 3

Q View related articles $\widetilde{2}$ 


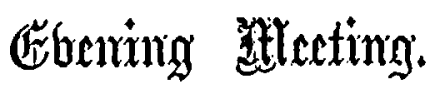

April 24, 1871.

Rear-ADutral A. P. RYDER, in the Chair.

NAXIES of MIEMCERS who joined the Institution betreen the 17th and 24th April, 1871.

LIFE.

Barstor, John A., Capt. 89th Regt.

ANNOAL.

Watson, T. C., Lieut. Iate 75th Regt. Little, II. A., Capt. 7th Fusiliers.

Cory, Arthur, Mrajor Bengal Staff Corps. IIudson, John, Licut.-Col. Bengal Stafr Bullen, Clarles, Comr. ret. R.N.

Iukc, J., Esq., Surrejor and Inspector Corps.

of Contract Work, $\Delta$ dmiralty.

\section{CONSIDERATIONS ON A NEIV FORII OF IRONCLAD PROPOSED}

\section{By Captain JoIr THEATLIr, R.N.}

Tre competition which has long been going on between guns and armour plates, is conclusively settled in favour of the gun over any plates that a sea-going ship could carry by the successful completion of the Woolwich 35-ton gun, with power to construct larger guns still in reservo. Under these circumstances, and accepting these conditions, it must be evident that the gun, that is, the power of the gun of other countries, and the size, weight, and porrer of our own gun, must be the chicf consideration in the design of the ships; and that the best form for a-sea-going ironclad must be that which exposes the smallest surface to shot striking at right angles, and possessing at the same time unquestionable stability, high speed, capability of carrying the full proportion of sail of former wooden ships, with full steam power, casy steering, and rapid turning.

Now that by the addition of 350 tons of ballast, the stability of our present ironclads is so far re-established as to admit of their being sent to sea without risk, in position of attack, that is, broadside-on, they 
expose a very large surface for shot to strike at right angles, probably not less than 280 feet by 20 feet of penetrable armour, which armour when penetrated is the very reverso of a defenco. Turret ships with high freeboard-rather au anomaly when with penetrablo sides-exposo about one-third less, but their hurricane-deck may be cut through and come down on tho turrets. $\Lambda$ writer in Blacliwood's Magazine for March, states that the " 'Audacious,' when broadside-on, presents an "arca of 6,670 superficial feet; and of these only 3,207 , or less than " half, are plated at all. There is a patch of 100 feet by 3 at the " water-line of 8-inch armour, which tapers down to $4 \frac{1}{2}$ inches at the "bow and stern; and the rest of the ship has nowhere any thicker "armour than 6 inches, the ends of the main-deck battery having " only 4 and 5-inch armour, while the cnds of the upper deck battery " are unprotected against a raking fire, and more than half the ship's "side is in the same unprotected state. A roll of $z^{\circ}$ would lift the s: 8-inch belt well out of the water, and a roll of $10^{\circ}$ would show the " unarmoured hull, and we hear that on the trials outside Plymouth " harbour, the ship, without a sail set, heeled over $16^{\circ}$, and the Ad" miralty have been compelled to have the rig of the slip altogether " altered, and her sails and masts largely reduced. Yet these are the " ships which are supposed to constitute our second-class of broadside si ironclads!"

It has been said several times, and it was repeated by Sir George Sartorius, at the close of the discussion on Admiral Fishbourne's lecture "On the Causes of the Insufficient Stability of Mer Majesty's late Turret-ship "Captain,' and of other Ironclads," that it was for the sailor to describe the sort of ship that he required, and then it wias for the naval architect to construct her according to the principles of his science. Therefore in the diagrams before you no more lines are given than are necessary to show the sort of vessel proposed. All -our present ironclads, and, excepting circular or star-shaped forms for coust defence, all vesscls which I find proposed in the Journal of this Institution, are based on the model of the Deal, or rather Dover galley as a type, the former being formed for beaching, whilo the latter lies afloat, a very good form for packets or passenger boats going straight on end, tut whose unhandiness for general purposes, and specially for ships of war, is shown, even when manned by those most accustomed to them in the indispensable "duck liunt" at all regattas; and this unhandiness has been further increased by the plough bow. It has been stated in this place that the "Monarch" took three hours to reer! I leave you to imagine the consequence if a ram was bearing down on her broadside.

The ressel, a diagram of which is before you, is taken from the Bombay fishing boat as a type, whose large spread of canvas is a sufficient guarantee of stability. It is the ruling principle in the form of most of the craft between Egypt and Japan inclusive. In the account of Commodore Perry's first visit to Japan, it is stated that a Japaneso boat took off some American Oficers to their ship quite dry in weather which quite wet through the Officers who went in their own ship's boat. The Chineso fast boats, the Thames wherries, and that noblo wherry, roL. $\mathrm{XY}$. 

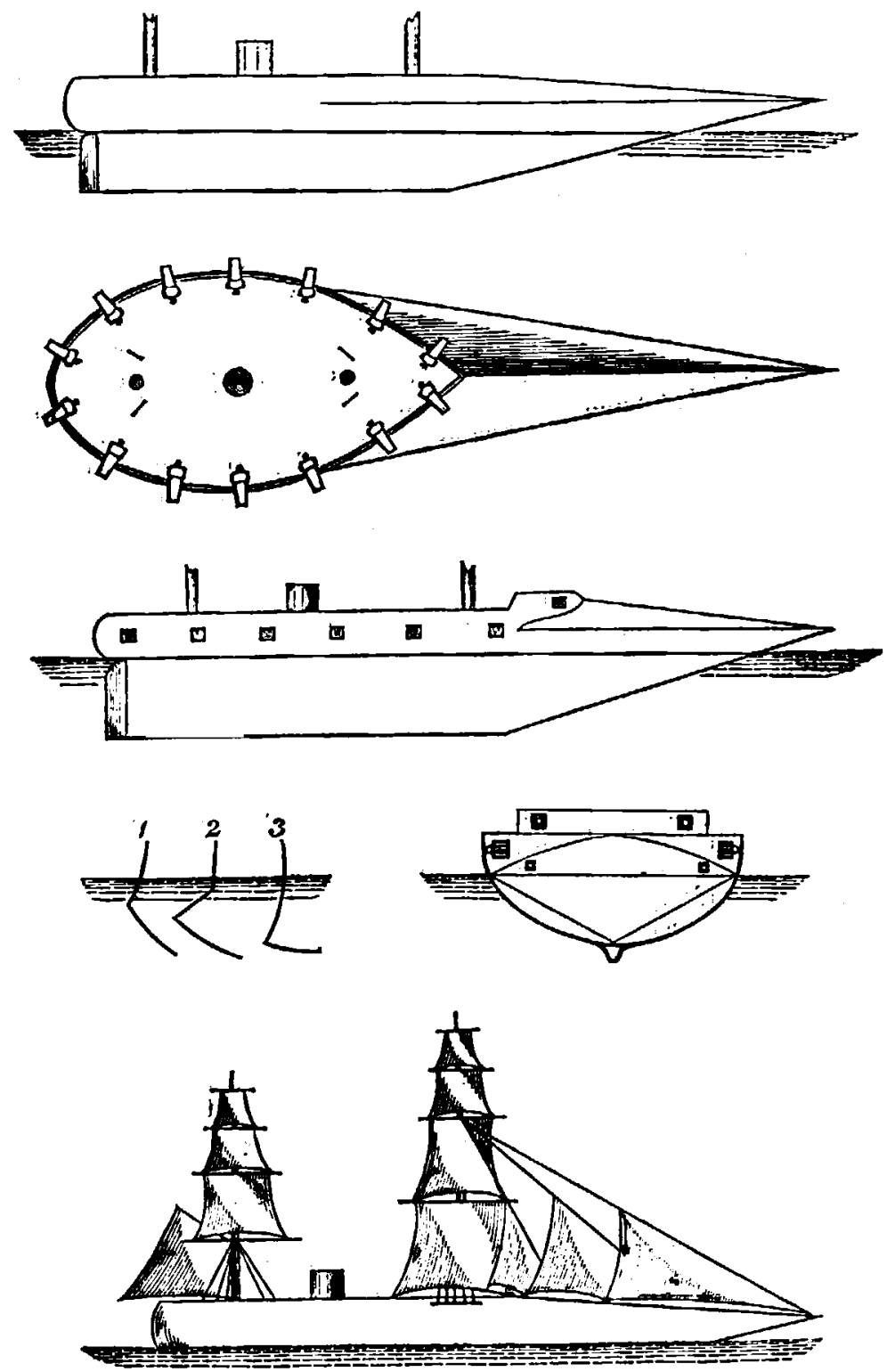
1. "Rupert."
2. "Derastation."
3. "Herculez." 
the beautifully-formed Lord Mayor's barge, are all examples of this principle, though tho barge, of course, is adapted only for shallow water. Taking these diagrams to represent a vessel whoso extreme length is 300 feet, her beam one-fourth of her length, 75 fcet, enabling her to carry 14 35-ton guns, reighing, with 23-ton carriages, 790 tons, that is litte more than double the extra weight of ballast put into our present ironclads to make them seaworthy. She will have an all-round fire without any impediment ; briuging, on Captain Scott's system of mounting, from 3 to 4 guns to bear, and 8 ahead and astern, and 7 broadside on Captain IIoncrieff's on cvery point of the compass; on Moncrieff's nevcr less than 5, without altering her position; while in proportion to the weight of metal carried, she exposes less than haif tho surface to shot strikiog at right angles than any other sen-going form, obtaining, by the oval, part of the advantage of the turet, though not quite to. the same extent as the circle for defeuce, but, on the other hand, superior to the revolving turret for attack by the guns being placed on a curve, thus having a gun always bearing on the attacking vessel.

At present no vessels are quite equal to our new breastwork-monitors, but they: will be enormously expensive, and we require a numerous flect as well as a ficet of ships individually powerful. The proposed form admits of the fullest use of sail* power, without any risk of the gear interfering with the guns; and, by the adoption of the hydraulic propeller, obriates the objection brought against the uso of : masts and sails on account of their fouling the screw if shot away. The following account of the "Hercules," as our best present sea-going 8 hip, is taken from Blackwood's Magazine for March:-

"The 'Hercules' is the only one of our first-class ironclads which " has yet been tried at sea, and it is due to her constructors to say that " she has proved a great success. Her armament is very powerfml, "and consists of 14 rifled guns, of which eight are of 10-inch, two of " 9 -inch, and four of 7 -inch calibre. Her water-line is defended by a "bclt of very thick armour, perhaps impenetrable at the thickest part "by any of the guns she carries; and extends for about 3 feet above " and' 3 feet below the water-line from stern to stern of the ship..$A_{s}$ " long, therefore, as the sea is sufficiently calm to confine her rolling "to $6^{\circ}$, it is probably impossible for any ironclad now afloat in any "foreign navy to deliver a shot which of itself can sink . her. "This "great defensive strength is, however, confined to her belt; the "buttery from which her largest guns are worked is only protected "with 6-inch armour, and experiment has shown that armour of that " thickness, with the ordinary backing, can be penetrated at a distance " of 1,000 yards, and at an inclination of impact of $30^{\circ}$, by the 9 rinch " rifled gun, and at close quarters by the 7 -inch rifled gun, such as is "carried by all except one of our present ironclads. But the "ITercules" " has other oxcellencies; she is, for an ironclad, a fair sailor, though "awkward in tacking or wearing. She has a speed under stcam of 6 14 lnots, and is a rery steady ship, and.can, therefore, use her great " offensire powers under conditions of sea in which a less steady ship

* The masts and sails aro not drawn to scale, but only to show the rig. 2 K 2 
"would be almost hors de combat. Of onr other first-class ironclads " the 'Sultan,' which resembles the 'Hercules' in most essential " points, has been launched, but has not been tried. It is said she is " deficient in stability." So far Blackewood. Broadside-on, her position of attack, the "Ilercules," with a length of 925 feet, exposes about 300 fect by 30 of penetrable armour. With my vessel the position of attack. will be stem-on; in this position she will bring, on Scott's system, four 35-ton guns, on Moncrieff's eight 35-ton guns to fire in a line parallel to the keel behind armour quite as secure as that of the breastwork monitors; and presenting an acute spherical angle to the enemy's shot. My vesscl's weakest point will be the broadside. Should slie be attacked on the broadside as well as ahead, she will bring. five or seven guns to bear, as repelling forces, but the defence will be weaker than stem-on, inasmuch as allowing for the great strength required for the gun-deck, she would probably not carry more than a 10-inch waterline belt of 6 feet, surmounted by 6 -inch plating throughout, but the wholo may be faced with 18 inches of teak (taking a leaf out of Mr. Kyde's book*) as the rood that splinters least and that suits best in contact with iron. Broadside-on, my vessel - would expose about 130 feet to shot at nearly eight angles at the water-line, to about 300 feet of the "Hercules," with the same armour. On the gun-line, and above, my next ports to the beam-gun recede $10^{\circ}$, the next two $20^{\circ}$, and the next $50^{\circ}$; this, with 24 feet from gun to gun, makes 96 feet, in all about 120 feet; that of the "Mercules" remaining at 300 feet penetrable armour, whilo the repelling force of $\mathrm{my}$ guns will be at least double the force of the "Hercules" guns.

I need say nothing here as to the advantago of masts and sails, over very large vessels navigated solely by steam, in point of economy, nor as to that of their being the only resource in case of damage to machinery. With vessels on a wind the greatest pressure, and of course the greatest obstruction to speed, is on the lee-bow. This pressure has been greatly reduced by the prolongation of the lines in the plough-bow, but the advantage has been more than counterbalanced by a further addition to the difficulty of steering and turning. In the diagrams before you, the entrance at the water-line very neally coincides with Mr. Scott Russell's line of least resistance; there is an upward pressure increasing with the speed of the ship, and this upward pressure is further increased by the action of the head-sails, which all have a lifting power tending to reduce friction in passing through the water. The following is an extract from the Globe of March 4th, 1871 :- "The Royal Conmission on the construction of ships, who "visited Devoriport this wcek to test the ironclads, haro condemned " the 'Waterwitch,' worked by hydraulic apparatus, and the ouly ship " of her class. The performances of the 'Ilotspur' as to speed, powrer, " and safety were satisfactory ; but owing to her weight /and form of "bow, which is built to allow firing straight alead, she lies dead in " the water, and when driving at full speed against a head sca, three " tons of water were taken in at port of the turret, which was experi-

* This, howerer, is a naral architect's question. 
"mentally opened for five minutes only. The Committec approve of " her for coast defence, but will decline to pronounce her suitablo for " ocenn royages."

As Admiral Elliot, who was a strong advocate for the hydraulic propeller, was one of the Committee, there must have been good reason for the condemnation of the "Waterwitch ;" but the principle has more than once so nearly reached success that wo may still look forward to it as our best motive principle. The immense quantity of water shipped by the "Hotspur" is probably owing to the concave shape of the plough-bow just below the surface of the water, the pressure being downward and therefore destructive to speed, and carrying the water upwards.

In a question of national existence,-for, deriring so much of our subsistence from abroad, were our feet defeated, wo might be starved into submission on the most humiliating terms without an enemy landing on our shores, - it would be a rery great mistake not to avail ourselves of the advantago to be gained by the use of the most powerful projectiles; the difference between an 18 or 25-ton gun and a 35-ton gun might render a doubtful contest certain, with fower damages to repair and with less or rery likely no time lost by absenceof the ship from her station.

With this vier I propose three classes of ressels, all having the same scantling, this class before you being the first-rates; the secondrates, of 260 feet length with 65 feet beam, to carry eight 35-ton guns, weighing, with carriages, 440 tons; third-rates, 220 feet in length with 55 beam, carrying four 35 -ton guns, weighing, with carriages, 220 tons; the first and second-rates bring four or eight,according to the system adopted,-guns to bear right ahead behind impenctrable armour, and the third will bring two or three under the same conditions. I do not allude in any way to gunboats carrying one gun. It must be borno in mind that tho smaller the vessel in a seaway, the greater the disturbance to correct aim, and that in case of a miss, it is of great advantage to hare another gun ready, as these guns cannot be reloaded very rapidly; and though the large ship may cost more, she will also bo worth a great deal more. In the next naval war we shall have to seek special precautions against that most destructivo weapon, Ilarvey's sea torpedo. In the trial between the "Royal "Sovereign" turret ship and the "Camel" with these torpedoes, the "Royal Sovereign" at anchor was supposed to defend herself against ten different attacks, the turret ship being armed with five guns. The torpedo was successful eight times out of the ten, each touch representing total destruction, the "Royal Sovereign" firing during the first attack seven times; second attack four times; third, fourth, fifth, sixth, and soventh attack twice; eighth and ninth attack only once. On the following day, with the "Royal Sovereign" under weigh, the torpedo ressel made six attacks, failing only once, the "Royal "Sorercign" firing ten, twelve, seren, two, five, eight rounds during the successire attacks; and it was remarked at the time that had these guns been shotted very few of the shot would liave struck the "Camel," this in smooth water, at an extreme distance of sixty 
fathoms, thus showing tho necessity of having guns laid for an attack in any direction.

In the article in Blacliwood, from which I hare reccired so much information, it is stated, that "Every break in the armour-plated side " of a ship is a necessary clement of weakness, especially in the pre" gent day, when breechloading rifles from the enemies' marines may " be expected to pour a volley through every open port-hole." Every ship of war of whaterer form must be a compromise between diffculties. The intention of the rifled gun is to enable you to destroy your enemy at distances of from one to two thousand yards; thus I cannot imagine where any body of riflemen could find a near-enough platform whence to dischargo a volley into any ports in case of the adoption of the Scott system instead of the Moncreiff.

\section{Extracts from MIr. E. J. Recd's "Our Ironclad Ships." \\ Chapter rii, p. 140. "Rolling."}

In fact, the hearier a sbip is, the greater is the resistance she offers to being set rolling, a statement which it is scarcely necessary to illustrate, as we aro all familiar with the fact. It is truo that great reight tends to sustain motion when it has begun, but eren then it does not increasc rolling. In fact, as far as the mathematical theory of rolling goes, a ship's behariour is entirely independent of her wcight, although the hearier ship requires a greater effort to set her rolling than a lighter ressel.

Chapter rii, p. 178. "Dimensions, Turning."

\begin{tabular}{|c|c|c|c|c|c|c|}
\hline & \multirow{2}{*}{ Length. } & \multirow{2}{*}{ Brcadth. } & \multirow{2}{*}{ Prop. } & \multirow{2}{*}{$\begin{array}{l}\text { No. of } \\
\text { men } \\
\text { stecring. }\end{array}$} & \multicolumn{2}{|c|}{ Circle. } \\
\hline & & & & & Yds. & Tine. \\
\hline 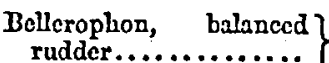 & 300 & $56 \cdot 1$ & $5 \cdot 3$ & 8 & 401 & $4^{\prime} 47^{\prime \prime}$ \\
\hline 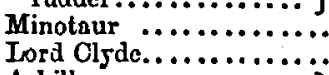 & $\begin{array}{l}400 \\
250\end{array}$ & $\begin{array}{l}59 \cdot 49 \\
58 \cdot 11\end{array}$ & $\begin{array}{l}6 \cdot 7 \\
4 \cdot 7\end{array}$ & $\begin{array}{l}78 \\
12\end{array}$ & 939 & $\begin{array}{l}7^{\prime} 38^{\prime \prime} \\
4^{\prime} \\
5.4\end{array}$ \\
\hline $\left.\begin{array}{l}\text { Achilles } \ldots \ldots \ldots \ldots \ldots \ldots \\
\text { Warrior } \ldots \ldots \ldots \ldots \ldots \ldots\end{array}\right\}$ & 350 & $58 \cdot 4$ & 6.5 & 一 & $\begin{array}{l}618 \\
760\end{array}$ & $\begin{array}{l}6^{\prime} 40^{\prime \prime} \\
7^{\prime} 46^{\prime \prime}\end{array}$ \\
\hline 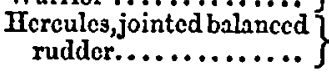 & 325 & ธ9 & $5 \cdot 5$ & 16 & 562 & $4^{\prime}$ \\
\hline
\end{tabular}

P. 181.

Oür expericnce with long and short ironclads may be fairly stated as follows-that the short ships may be driven as fast as long ships by a moderate addition to their cngino porser; that in turning power and gencral handiness under steam and eail, the short ships are much superior, and that the great reduction in prime cost of short ships rauch moro than males amends for the addition to the steam power.

Chapter ix, p. 196. "Forms and Proportions."

In armourcd ships, as the extent and thichness of the armour aro increased, the proportion of lingth to breadth should be diminished and the fulness of the water 
lines incrensed; the shorter fuller ship can bo propelled at as great spoed the longer finer ship, with about the samo or only a littlo greater horse power.

In longer ironclads tho proportion of frietional resistance becomes considerably increased.

\section{Exlracts from Mr. J. MI. IIyde's Lectwre on Deflecting Armour Plated Ships for Coast Defence.}

Journal of the Royal United Sercice Institution, No. liii, pp. 133, 131, 139.

IIr. IIyde's experiments were mado with a gun representing a 25-ton 12-inch 600 pouuder, at a range of about 17 feet, representing 70 yards, and the rcsults bore the same proportion to those of the serrice gun.

With a target representing the angular sido of his ship ( $20^{\circ}$ from horizon) pno half faced with rood and the other bare, the wood mado tho shot ricochet; the metal showed a small iridentation only.

Since writing the abovo wo have had letters from Sir Spencer Robinsou in the newspapers, stating that other powers are building on tho models of "Ilercules" and "Derastation." It is clear that Russia is putting efficiency before economy, and that part of her new loan will go to pas for the heavy breechloading guns of which we read in the Standard of the 8th instant. Prussia in her last two wars has acquired ample means of procceding on the same scale. There can be no question as to the object of these armaments, and unless wo are prepared to neet them our prospects are not very gratiiying. I thereforo propose to increase the scale of my ship to 340 feet length, 85 feet beam, and to guns of 60 tons, throwing 1,200 or $1,500 \mathrm{lb}$. shot; and that no time slould be lost in testing Captain Mroncrieff's system, which either increases one-third or double the force of tho ship. In one of our present sea-going ships, - perhaps as she is without ports the " MIonarch" would be the best, - three guns of the same calibro should be substituted for the turrets, there would still.be space for two more, and thus her attacking force would be donbled. As it is one of the ineritable consequences of the progress in ships and guns that the ship of to-day becomes obsolete to-morrow, it is perhaps wisest, and in the end cheapest, to go to rork at onco on the largest scale possible. Captain Colomb's most important and suggestive lecture on "The Attack and Defence of Fleets," shorrs the advantage of the ram orer the gun as a weapon of attack, and also that the proportionate power of the gun has receded as its size has increascd. Since the war of the first Napoleon, wo have had two actions of feet-to-fleet-Navarino and Lissa; but we have had Algiers, Acre, and Sebastopol; Cronstadt was considered unassailable with the menns wo had then at our disposal. In the American civil war, ships were successful orer forts at New Orleaus, Mobile, Fort Fisher, and failed only at Charleston. In all these cases the gun was the only possible weapon.

In addition to the o:her advantages of the form I propose, I submit that the proposed vessel possesses very superior advantages as a ram, the weight of head and stem assisting. It has been found with projectiles that the sharper the point, the deeper the penetration; should this bo so with a ship, as is most probable, this ressel would simply split any other in two and pass through her, while as a defence, pre- 
senting her stem, the approaching ram would either spit herself on the point or pass along side without doing harm.

\section{Torpedoes.}

As all ships can uso torpedoes, I look forward to tho timo when ships will no more be sent to sea without a store of Harvey and other torpedoes, than without boats or anchors.

- According to Captain Dawson's lecture, the force of torpedoes does not extend in water beyond 20 yards, so that ships of the proposed form may easily swcep a channel clear of stationary torpedoes by procceding in pairs with the stream or kedge chain extending across the channel from outriggers on the off bow of each ship, stiffening the chain with spars if the bottom is steep; an operation which could not be carried out by ships of tho present form.

With the supremacy at sea, blockades may be secured by a torpedo cordon moored across a harbour's mouth, crcluding access or egress of any kind.

In the First Lord's speech on the naval estimates ho stated, that "It " secmed to him to be an impossible problem to combine a first-rate "fighting ship with a first-rato sea-going ship." It has bcen my endeavour to combine a first-rate seaboard with a first-rate stenmer, and first-rate sailing ship with a first-rate fighting ship, armed at all points, whether for gun, ram, or torpedo warfare.*

The Cinarnyax : Docs any gentleman wish to ask any question or to makc any obserrations upon the paper just read? I should like to lead off by asting two questions. What is the freeboard of jour largest ressel? Also what is the leight of the hamse-holes abore the mater?

Captain Darrsox, R.N.: The only questions I should like to ask are whether these are a scries of guesseg, or whether there hare been aus calculations mado to justify the supposition that a ressel of thoso dimensions would carry the reights that are there stated? And how are we to guard against the guns on the IIoncrieff system firing into ono another? I would also say that you misquoted me. I nerer Eaid that torpedoes could strike a ressel 20 yards from the place of explosion; it was 10 or 15 feet.

Captain Whestrer: That is the better for my ressel.

Admiral of the Flect Sir Grozas SArTorids : I wish to ask you, in attacking as a ram, what rould be jour mode of attack? I do not mean end-on, becauso no ram of that kind would attack ced-on. But in attacking, how do you calculate upon attacking as a ram a ship on her broadside? Also what is the power of penctration?

Mr. IYDE, C.E. : I should liko to make a fer remarks. It appears from tho design that Captain Wheatley has produced, that all his guns would bo placed in one huge battery. Now, unless the sides of his ship would be inrulnerable, the effect of shells

* Captain Wheatley has requested that the following propositions may bo added to his paper.-ED. :-

1st. Neither light draught of water nor reliable stability under sail are attainable with narrow beam.

2nd. High specd is only attainable by considerable length in proportion to beam.

3rd. Abundant proof exists that there is no absolute necessity for this length to be in the form of an clongated rertical parallelogram.

4th. Abundant proof exists that according to the clongation of the abore-named form the efficiency of ironclad ships of war is diminished. 
getting into that battery would, I think, bo rather scrious for the crew who wero fighting the guns. It has been argued that the great point in all future warfare should be to kecp the shells out of a ship, because they seem to do more mischicf than any other projectile. So that unless the sides of the ships were practically invulnerable, shells would necessarily get through; and you can well imagine the effect they would produce among a crew so confined eren in so huge a batters. The forward end of the ship, of course from its construction and from the angular sides it presents, rould be practically inrulnerable. Now, if it be necessars to mako the end of the ship angular, and hence invulecrable, why not carry out the angular side all round tho ship and place your battery in the turret gun-carriago? Turrets aro really insulnerable gun-carriages; and if the turrets were armed with these modern 35-ton guns, the power of which is hardls jet known, the turrets being practically inrulnerable, the shells then would not get in among the crew. The remark I wish to make is simply this, that if it has been shomn that the sides of our ships aro penetrable to our modern shells, then these vertical sides would still be practically uscless for tho protection of the gunners and those who serre tho guns. Also if it be necessary to make the borrs of the ship angular to keep shot and projectiles out, why not carry tho angular sides all round tho ship?

The Charras : Perbaps, Captain Wheatley, you will now reply. You did not mention the speed or the coal carried.

Captain WResteEx : Your first question was with regard to the height of tho freeboard. The lower sills of the port are 7 feet $G$ inclies abore the water-line, and of the hawse-holes 7 feet. That is about the height of those of our frigates in tho last war. Of course they may be mado a little higher if it is necessary. With the 35-ton guns, on Captain Scott's sJstem, it is necessary to liare the 'trreen decks rather higher than on Captain Moncrief's system, the greatest diameter of the gun being 4 fect 8 inches, to allow for the gun-carriage and for the necessity of clerating and depressing the gun. Captain Dawson wants to know on what data the ressel is designed. I can only say that it is designed from the models which we hare before us, just as others are designed, from the Deal galley, or rather the Dover galley. It is the same desigu increased to the size and necessity of a man-of-war. I am rery much obliged to him for putting me right about the torpedo. I gare tho torpeclo credit for more porier. It is more casily got rid of by a ship of that form, that is to say, the engineer's torpedo fixed upon the ground. Sir George Sartorius wished to noow about llac attack. Tho nttack mould be nado by the ram stem-on. I know of no other way in which that ram could bo used. The point of the ram is 7 feet 6 inches 'abore the water-line. The projection of the stem of the "Rupert" is I suppose about 4 feet below water-line, that of the "Derastation" still lower, and that of the "Hercules" a bout 10 fect below the water-linc. If you brought the ploughbows of these ressels against my ship they would not touch any part of her; and again, if they missed the point lhey would slide along the side and could not do any harm.

Sir Grorae Samionits: But when you are attacking an enemg's ship as a ram, the point of your ressel would bo considerably abose the water-line.

Captain Wnestrex : It would strike the ship a little abore her belt.

Sir Geozas Sarronits: Tho grent object to be gained by a ram is to etrike underneath and sink the ship, which jours mould not do.

Captain WrEsTIEX : By the ram striking abore the belt and making a widc hole, not a thin hole like the cut of a knife, the reights of the ship's head and stern would immediately come into play to break her back. The foro and aft parts would part eren from the force of the blors; there would be nothing to sustain the head and stern of the ship attacked. The head and stern is much hearier than the midship section; and if the midship section is cut through, she would breal in tiro.

Sir Q. SaRtorius: If the tro ressels were going fast through the water the noso of jour ressel mould be run off.

Captain Wrestrex : It might be; but recollect it is not a thin plate, it is supported on cach side; and if it ras, breaking it of would do no great liarm. But that remains to be seen. I should be rery glad to see an esperiment on a small scale with 
a ressel of this form. Speaking nbout the effect of shells, does the gentleman who asked the question mean vertical or horizontal fire of shell, because that would make a differenec. The sluip is impenetrable to the horizontal fire of shells; sou cannot protect the ship against rertical fire.

Mr. HrDE: But you can drive a shell through a 10-inch rertical plate.

Captain Werestuer : This is the angular form of the ship's bow; and she brings eight guns to bear on the Mroncricff system.

MIr. HYDE : But I mean on tho broadside.

Captain Wrestrer: On the Monerieff system all theso guns turn on tho brondside, and there is a greater force of guns than in any ressel of any other form. The "IIercules" can only bring four guns to bear.

Captain Giurone, R.X.: If it is merels a question of tho damage done by shells after entcring a batterr, it is casily obriated by laring a trarcreo betrcen the guns.

The Cirisersax: With regard to tho report you quoted from a west country paper about the risit of the Committeo of which I am a member, the words used could not bo justified at all. The words used by the person who wrote in the paper expressed no opinion at all; thereforo you mas set that on one side. (Captain WrestLex: Very well.) I am sure that I only express the sentiments of all present by returning our thanks to Captain Wheatley. All papers on these subjects aro rery interesting, and anybody who will contribute to our knomledge will almajs be wclcome.

Captain Wheatley is desirous that the following notes should be added, as he did not at the time clcarly understand the question put:- "With regard to Captain Dawson's question, as to previous calculations, it is answered, by the opening statcment that nine is only the "sailor's ressel," its construction is for the Firal Architect. I know of no formula for calculating the tonnage or speed of such a ressel, or whether those cited for the present forms would apply; but taking the tonnage to bo nearly that of the Mlinotaur's, it must bo ample for/tho meights proposed.

"With respect to the further discussion on the ram, such questions can only bo decided by esperiment. Sereral ressels aro sunk crery jear by collision, without being struck by a plough-bor. In my opinion, in the caso referred to by Admiral of the Flect, Sir George Sartorius, as to the rammed ressel going at speed, the knifelike projection of the plough-bow is more likely to be wrueg off, and with greater danger to tho ram, than with my ressel, 2 double wedge strongly supportcd; a tredge is also the form that most casily withdraws from the hole it has made."

\section{ARE THE ROYAL MIARINE FORCES A NECESSARY AUXILIARY TO.THE ROYAL NAVY?}

$$
\text { By Mrajor-General Schomera, G.B., R.M.A. }
$$

Is the revolution that has taken place during the last few years in warlike matters, naval and military, a question is often asked, Is there now any necessity for the maintenance of the Royal Marine Forces as an auxiliary to the Royal Navy?

The question is an important one, for the marines have been hitherto not only an auxiliary to the Navy, but its first reserre, a reserve which could be always depended on; which nerer failed. $\lambda_{\text {s }}$ an Officer of Marine Artillery, I crave permission to cxamine this question, and will endeavour to do so as dispassionately as possible. 